Meta

Journal des tradlucteurs

Translators' Journal

\title{
Translating for Enjoyment
}

\section{Margaret Arnaudin}

Volume 27, numéro 2, juin 1982

URI : https://id.erudit.org/iderudit/001903ar

DOI : https://doi.org/10.7202/001903ar

Aller au sommaire du numéro

Éditeur(s)

Les Presses de l'Université de Montréal

ISSN

0026-0452 (imprimé)

1492-1421 (numérique)

Découvrir la revue

Citer cette note

Arnaudin, M. (1982). Translating for Enjoyment. Meta, 27(2), 229-230.

https://doi.org/10.7202/001903ar

Ce document est protégé par la loi sur le droit d'auteur. L’utilisation des services d'Érudit (y compris la reproduction) est assujettie à sa politique d'utilisation que vous pouvez consulter en ligne.

https://apropos.erudit.org/fr/usagers/politique-dutilisation/
Cet article est diffusé et préservé par Érudit.

Érudit est un consortium interuniversitaire sans but lucratif composé de l’Université de Montréal, l'Université Laval et l'Université du Québec à Montréal. Il a pour mission la promotion et la valorisation de la recherche. https://www.erudit.org/fr/ 
BLOC-NOTES

\section{TRANSLATING FOR ENJOYMENT}

Many are the translators, writers and literary enthusiasts who are intrigued by literary translation. Few, however, indulge in their predilection, opportunities for study being so limited : usually it is only by enrolling in a formal translation programme that a beginner can have any guidance in a field that only the most scholarly dare tackle on their own.

Even when courses are available, students often opt for more "down-to-earth" activities, for it is not generally held that literary translation has any practical application in a modern translation bureau. And, indeed, it is a field apart. But students of literary translation often discover it provides them with a creative and imaginative approach to translation problems that proves invaluable in every field of translation, and that far from confining them to a single style it gives them a facility for adapting to any type of writing required during their careers, be it technical, legal or journalistic. For literature embraces a myriad of styles - contrary to the misconception that literary writing is fiorid, as opposed to technical writing which is concise. Literary translators would willingly vouch that there is no better exercise in being concise than the translation of poetry.

In the fall of 1979 the Societe des Traducteurs du Québec made up somewhat for this dearth of opportunity by offering a seminar in literary transiation. The seminar was conducted by Daniel Slote, a professor from the University of Montreal and McGill University. Professor Slote is a poet, literary translator and scholar. But above all he is a translator who translates for enjoyment and who has the capacity for sharing his enjoyment with his students.

For literary translation is not taught: it is enjoyed. Its skills, like those of any other type of translation, are best acquired in an apprentice situation, and this situation was provided by having the members actively participate from the outset.

Professor Slote showed a sincere respect for every piece of work submitted to him, a respect he unconsciously communicated to his students. Thus he created an atmosphere wherein they quickly developed a sense of discrimination, for they willingly defended and criticized their own and each other's work. During the seminar copies of the students' translations were provided, which facilitated this amicable exchange of opinion. At times these were uncorrected, and participants were asked to spot mistakes, weaknesses and strong points. The professor himself tactfully intervened to settle differences of opinion, dissipate doubt and point out problems that had been overlooked. No model translations were provided: rather the more successful solutions to the thornier problems in the texts were indicated. The students felt that their translations, different from each other as they were, could stand, after the suggested revision and correction, as suitable renditions. In fact, after each text had been thoroughly studied and discussed, a final 'class' version was drawn up, using solutions that had been agreed upon by the participants.

Texts were chosen that offered a variety of literary modes and styles. The first was a short story by Jean Ray, a story that begins as a simple narrative that turns into a wild fantastic dream. The style was not demanding, and the students had a chance to give free reign to their imaginations. The next text - the most lyrical chapter from Alain Fournier's Le Grand Meaulnes although dreamlike as well, presented problems of a totally different nature : translating a text by a modern author writing in a classical style, finding ways of giving it an 'old-fashioned' touch. But most difficult of all was rendering it in a style as simple and pure as the original. 
After the Fournier text, translating scenes from Michel Tremblay's play Bonjour là, bonjour meant a shift from the sublime to the ridiculous, a task that some performed with obvious relish, as though on holiday from the confines of normal syntax and grammar. The students discovered that although the level was decidedly low, there was more than one, which depended on the age and background of each character. Some translations were rendered in dialect and others in slang, in some cases with an amusing regional touch. The class was then given a selection of poems by several authors and asked to translate those that appealed to them most. The problem here was to render the hermetic so as to make the translation as open to interpretation as the original. In addition, the psychological novel Moïra by Julien Green provided narrative quite different from that by Ray, for students found they had to penetrate into the mind of the protagonist in order to render the somber mood.

The final text was the last chapter from l'Oeuvre au noir. The students were in the midst of revising their translations of this work when Yourcenar became a member of the Académie Française, an appointment they were fully able to appreciate, after having worked intimately with her sonorous and rhythmic latinate style.

The class was particularly impressed with the variety of styles and levels they had encountered. They were intrigued to discover their affinities for certain authors : the Tremblay text revealed to some that they had an ear for dialogue while others discovered their reluctance to lower their level of speech; the lyrical translations of some of the poems showed a flare for poetry; where some were overwhelmed by the ponderous Yourcenar style, others blossomed.

Exploring such affinities and deficiencies is part of the fascination of literary translation. It is both a creative and a practical way of studying literature, a discipline that gives firsthand experience in writing literary styles. As it requires students to transpose sounds and rhythms, they come to listen to what they write and read. This is a process that is not normally available to students of literature, who produce paraphrases or explanations of the texts they study in what is often a paltry imitation of the critics' style. The process of literary translation is a close reading that transcends explanation and interpretation; it enables the student to participate in the re-creation of a work of art.

Students of literary translation find that they are drawn in a special way to the literature of their mother tongue, seeking to discover how master writers handle the problems they come across in their translating. They learn to appraise good writing with a craftsman's eye.

The course gave the members a chance to dispense for a while with such mundane preoc- cupations as word counts and cents per word and to translate for pure enjoyment, to render to their own satisfaction some remarkable pages of literature that they have, in a way, claimed for themselves. Courses such as this show that literary translation is not solely the domain of the highly erudite; it is an absorbing pastime and a rewarding discipline for literary amateurs in the true sense of the word - and particularly for that breed of translator who cannot resist a challenge.

Margaret ArnaudiN 